\title{
Helping Agritourism Visitors Learn During Their Visits ${ }^{1}$
}

\author{
Kathryn Stofer and Joy N. Rumble 2
}

Agritourism is a growing industry in Florida, combining the state's assets in tourism and agriculture to provide a learning and entertainment opportunity for Florida residents and out-of-state visitors alike (Florida Agritourism Association, 2018). Adding agritourism to traditional production agriculture can provide operators with a new revenue stream, as well allow them to support local agriculture as a whole through education (Gil-Arroyo, Barbieri, \& Rich, 2013). In order to support agritourism operators in offering meaningful programming to their visitors, this document outlines ways to incorporate meaningful educational opportunities into your operation. To support this, we present the results of focus groups with Florida residents as to their topical interests for learning about agriculture.

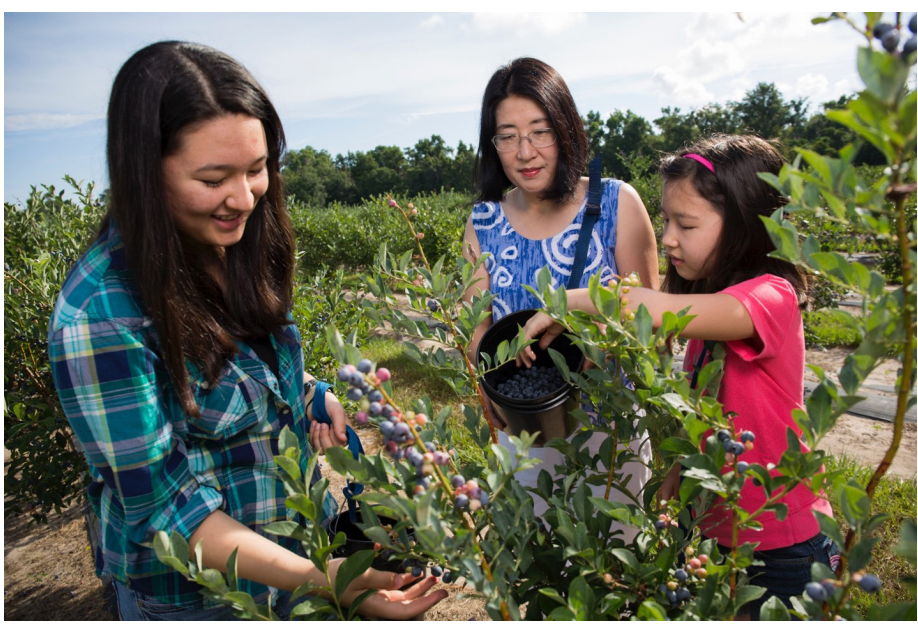

Figure 1. A family visits a blueberry u-pick operation, an example of agritourism.

Credits: UF/IFAS
This document is one of several on agritourism designed to help you improve or start your own agritourism operations.

As agritourism grows throughout the United States, several researchers in other states have examined agritourism from both the provider and visitor perspective (e.g., Brown \& Hershey, 2012; Flanigan, Blackstock, \& Hunter, 2014; Gil-Arroyo, 2012). These studies have revealed typical agritourist demographics, preferences for admission price and amenities, and methods of hearing about agritourism opportunities. However, to date, no research really looks at what topics visitors are interested in learning about when they visit.

\section{Design Your Experience}

Creating experiences that engage visitors and enlighten them about your operation or broader issues of Florida, national, or international agriculture involves strategic planning and, ideally, ongoing feedback from visitors and subsequent revisions. However, with a little time and effort, you can provide value that may entice visitors to come back time and again.

An agritourism learning experience can have many similarities to an Extension program. Based on principles for program planning for Extension (Diaz, Gusto, \& Diehl, 2017), we suggest five basic steps to consider when designing an experience: 1) understand the situation you want to change, 2) determine your audience, 3) determine desired outcomes, 4) design and enact learning activities, and 5)

1. This document is AEC645, one of a series of the Agricultural Education and Communication Department, UF/IFAS Extension. Original publication date June 2018. Visit the EDIS website at http://edis.ifas.ufl.edu.

2. Kathryn Stofer, research assistant professor; and Joy N. Rumble, assistant professor; UF/IFAS Extension, Department of Agricultural Education and Communication, Gainesville, FL 32611.

The Institute of Food and Agricultural Sciences (IFAS) is an Equal Opportunity Institution authorized to provide research, educational information and other services

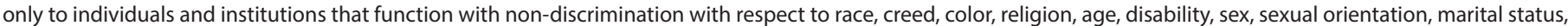

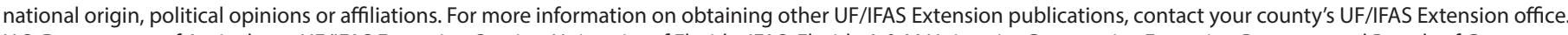
U.S. Department of Agriculture, UF/IFAS Extension Service, University of Florida, IFAS, Florida A \& M University Cooperative Extension Program, and Boards of County Commissioners Cooperating. Nick T. Place, dean for UF/IFAS Extension. 
evaluate your participants' experiences. Steps 1-3 may not happen in that order, and you may find yourself repeating or revising steps 3-5 as time goes on.

\section{Understand the Situation}

First, you must have an idea about what your visitors currently want to know or behaviors you might want visitors to change. You can understand the current situation in a variety of ways. You could work with your Extension personnel to find existing resources on the topic or behavior, as they or their research colleagues may have recent information on Florida residents in particular. You could read trade publications, which may alert you to policies under review that you may want your visitors to support, or which report recent consumer survey results. Finally, you can get information directly from your desired audience through your own surveys, observations, or interviews.

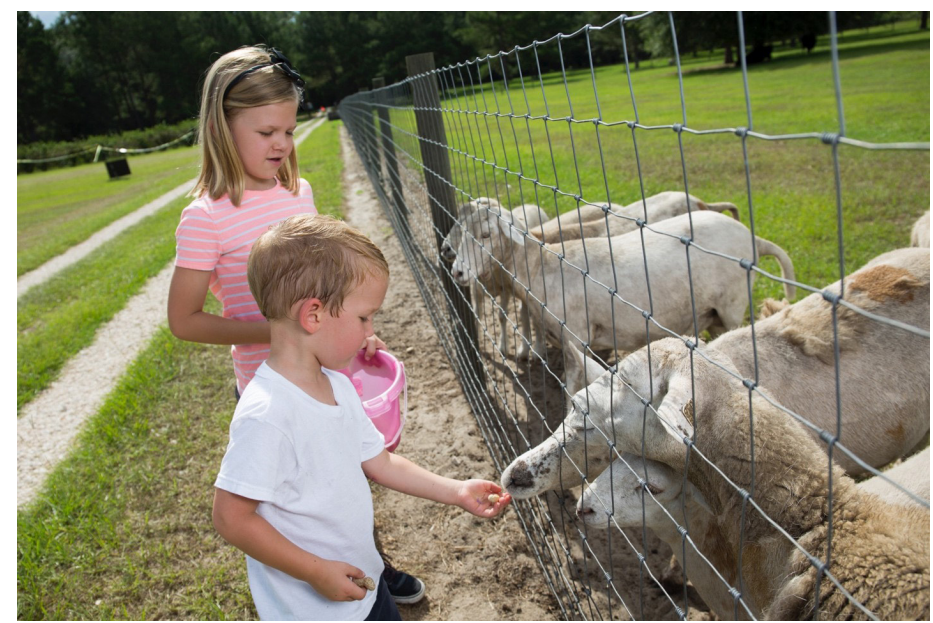

Figure 2. Perhaps you have observed people improperly feeding your animals, and you want to develop an experience to encourage correct feeding habits.

Credits: UF/IFAS

\section{Determine Your Audience}

Another component of the process is determining who you want to serve during your experience. This may happen before you determine the situation you will address.

Think about defining your audience based on one or more characteristics, such as age, location of their residence (e.g. local county resident, Florida resident from another part of the state, or out-of-state visitor), type of group with which they may visit (family, friends, religious, scouts, $4-\mathrm{H}$, school), repeat or first-time visitor, and amount or type of agricultural background, among others.

In general, the more specific you can be about your audience's characteristics, the more you will be able to serve their common needs. For example, if you are too broad and wish to address "adults," you may find that you cannot easily determine what all adults are interested in, even related to a narrow topic such as food safety. Some may be interested in preparing the fresh foods they buy at your operation to eat right away, while others may want to know about canning and preserving for long-term storage. However, if you want to offer a program experience for local county commissioners, you are more likely to be able to understand what you can offer that matches what they desire. For additional information on Florida residents' topical interests, see the results of recent focus groups in the section below, "What Visitors Want to Learn During an Agritourism Visit”.

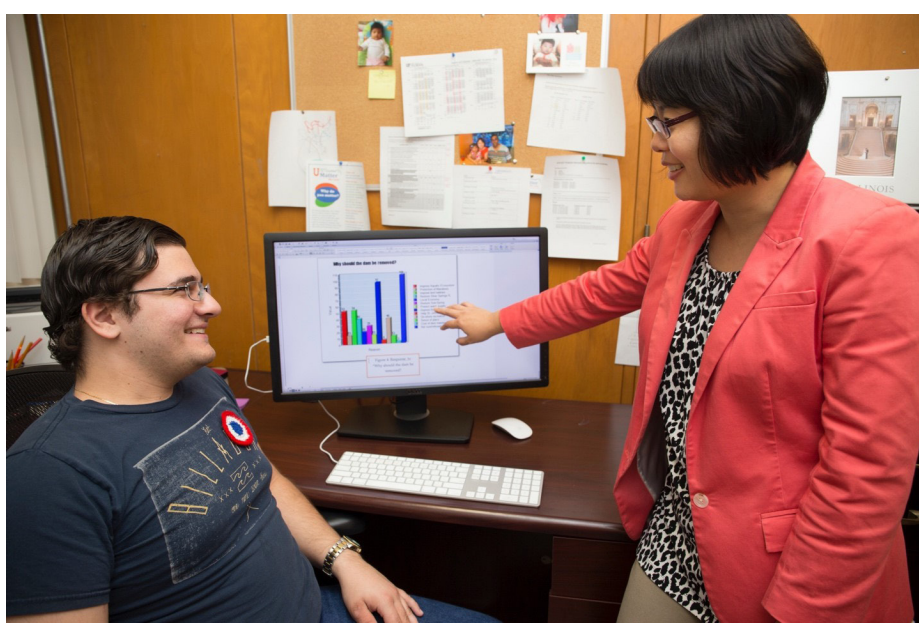

Figure 3. Use data about your audience to help you plan your experience.

Credits: UF/IFAS

\section{Determine Desired Outcomes}

Using what you know about your audience and their situation relative to the topics on which you might offer learning experiences, you can decide what you ideally want your audience to walk away knowing or doing. These outcomes can include short-term and longer-term outcomes. For example, you may want the audience to contact their legislators immediately on an issue of local importance, or to support agriculture in general by buying local products, or both. You must determine your desired outcomes before deciding on your activity to have the best chance of reaching your outcomes.

\section{Designing Your Experience}

Now that you know the "who" and the "what," you can go about determining how you will impact your audience with the type of experience you implement. You might decide to offer self-guided experiences, online experiences, staff- or volunteer-led experiences, or a combination. You 
may offer one-time activities, a series of recurring events, or an ongoing opportunity. For more detail on what Florida visitors desire in the types of experiences they engage in during agritourism visits, see the companion publication to this one, "Selecting the Right Type of Educational Experience for Your Agritourism Operation," http://edis.ifas.ufl. edu/wc304.

\section{Evaluate Your Experiences}

Once you implement your learning experiences, evaluation can help you decide how well they are working for both you and your visitors. Evaluation for you and your staff can be as easy as counting how many visitors participate and informally asking how the staff feels about the effort that is involved. Evaluating visitors can be as informal as judging participant attitudes by their expressions during the experiences, listening to visitor comments during and after the activities, or inviting visitors to fill out comment cards. Evaluation can also be much more in-depth, involving paper or online surveys and more extensive interviews. For more information on evaluation, consult your Extension agents and the EDIS publications in the Resources section. The most important thing you can do with evaluation results of any type is to act on them by refining your experiences.

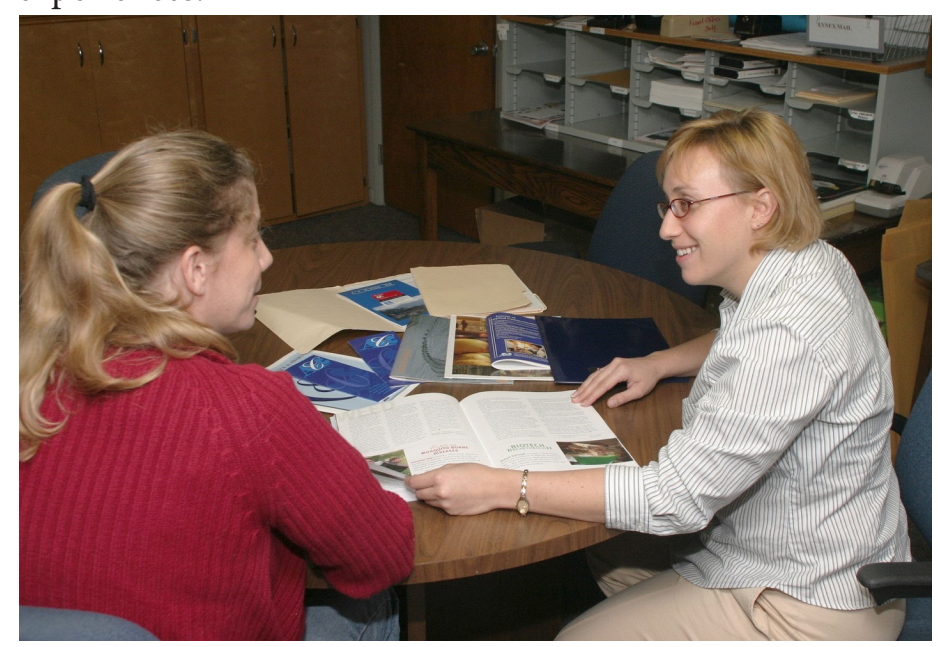

Figure 4. One way to evaluate your activities or materials is to interview people and ask them to comment on the experience. Credits: UF/IFAS

\section{How to Decide What Content to Include in Your Agritourism Experiences}

With all the possible content to talk about or skills to demonstrate, it may seem overwhelming to decide what is best for your operation. The good news is you do not need to try to cover all topics with a single operation. Here are some ideas to narrow down what content to include:

- Decide which topics already fit with your production. If you do not raise animals, do not try to cover animal topics. If you do not grow exotic fruit, you do not have to talk about how to select a ripe jackfruit.

- Determine who will be sharing the content, if you will have live-person-led programs such as tours, demonstrations, or presentations. Use their existing expertise to determine topics.

- Ask your local community. If you already have agritourism operations, ask your current visitors what content they would like. If you are thinking of starting new agritourism venture, ask friends, family, and other local people who are your likely initial visitors. For ideas on evaluating your audience in this way, consult with your local Extension agent.

- Ask other local agritourism operations, or visit their web sites or even the operations themselves. Are there areas of agriculture they are not covering that you could? Partnering with neighboring ventures could allow you to cross-promote your operations and even offer special event days that combine visits to several operations.

- Consult your local Extension agent. She or he can help you think about the audience you might want to attract, such as local or out-of-town visitors, and tailor your content offerings to that audience. Extension also has resources they could provide you, such as a series of fact sheets on particular Florida commodities.

- Consider offering skills-based workshops. These may be offered infrequently and may require participant pre-registration. You can also repurpose the general information about these same skills, such as what types of fertilizer and amount of water and sun to use in more frequent presentations of information or handouts.

\section{What Visitors Want to Learn During an Agritourism Visit}

Finally, we offer some insights into Florida residents who reported their interests in agritourism and, in particular, the topics they would like to be able to learn about during agritourism visits. While not all visitors expected to learn something during a visit to an agricultural operation, many expressed interest in taking home new knowledge and/or skills. Results from focus groups conducted in Florida in 2016 provide some insights into what Florida residents may 
be interested in learning about while visiting agritourism operations (Stofer, Rumble, \& Anderson, 2018).

\section{Knowledge}

Visitors mentioned the following topics they wanted to learn about:

- Food production

- General farming practices (organic vs. conventional); hydroponics, conventional breeding, and GMOs; the role of insects; and pesticides and fertilizer use

- Process of growing and the growing season

- Production processes, such as a working dairy farm or cattle ranch, juicing operations, and the sourcing of elements in the production process

- Source of their food

- Fresh vs. store-bought

- How food goes from farm to table

- Locally grown vs. imported

- What crops are native

- History

- Of particular crops and products

- Of the area, because some farms have been in families for generations

- Health

- Medicine

- Nutrition

- Food safety

- Animals and plants

- Ecological conditions and the environment in general

\section{Skills}

Participants also expressed a desire to learn skills related to food production and selection, as well as trying more farm-based skills, such as shearing sheep or milking cows. These answers varied more, but in general, people were interested in:

- Food production

1. How to start raising vegetables and fruits in your yard or community

2. How to grow particular crops in their local area, including pesticide or fertilizer use, appropriate varieties and water amounts, timing of planting and harvesting, and how weather and soils affect crops

3. New ways to grow crops, such as in raised beds or containers

- How to raise animals

- How to select ripe fruit and vegetables and products in season

\section{Summary}

Florida residents are interested in visiting agritourism operations for many reasons, including entertainment, purchasing products, connecting with nature, and learning about local agriculture. By tailoring your operations to offer information that visitors say is valuable to them and in ways they are most eager to participate in, you increase your likelihood of adding a successful alternative source of revenue and even potentially boosting your traditional production activities. Agritourism can support your local agricultural community, as well as agriculture throughout Florida and the US. To read more about plans for sustaining agritourism in Florida, please consult UF/IFAS Extension's strategic plan for agritourism listed in the resources section.

\section{Additional Resources}

Commodity Fact Sheets: http://branding.ifas.ufl.edu/ postersfact-sheets/

A state-wide plan for agritourism can be found here: http:// www.piecenter.com/issues/food/local-food/ (under the "Promoting specialty crops through agritourism: Producer professional development" tab)

\section{References}

Brown, L., \& Hershey, C. (2012). Agritourism in Wisconsin from the Consumer Perspective. Retrieved from http:// secure.wisconsinaquaculture.com/Docs/530.PDF

Diaz, J., Gusto, C., \& Diehl, D. C. (2017). Developing a Program Plan Based on the Program Planning Cycle. AEC628. Gainesville: University of Florida Institute of Food and Agricultural Sciences. http://edis.ifas.ufl.edu/wc290

Flanigan, S., Blackstock, K., \& Hunter, C. (2014). Agritourism from the perspective of providers and visitors: a typology-based study. Tourism Management, 40, 394-405. https://doi.org/10.1016/j.tourman.2013.07.004 
Florida Agritourism Association (2018). Home. Retrieved from visitfloridafarms.com

Gil-Arroyo, C. (2012). What is agritourism?: reconciling farmers, residents and extension faculty perspectives (Master's thesis). University of Missouri. Retrieved from https:// mospace.umsystem.edu/xmlui/handle/10355/15257

Gil-Arroyo, C., Barbieri, C., \& Rich, S. R. (2013). Defining agritourism: A comparative study of stakeholders' perceptions in Missouri and North Carolina. Tourism Management, 37, 39-47.

Stofer, K. A., Rumble, J. N., \& Anderson, S. (2018). Florida Consumers' Perceptions of Agritourism Focus Groups (No. PIE16/17-03a). Retrieved from http://www.piecenter.com/ wp-content/uploads/2015/09/Agritourism-2017_FocusGroup-Report_Final.pdf

\section{Acknowledgements}

The development of this document was supported by a Florida Department of Agriculture and Consumer Services Specialty Crop Block Grant. 